\title{
Pengaruh Masase Fundus Uteri Dengan Pendidikan Kesehatan (Video Masase Fundus Uteri) Terhadap Penurunan Tinggi Fundus Uteri Ibu Postpartum Di RSUD Pandan Arang Boyolali
}

\author{
Elisa', Luluk Dwi Royani², Wien Soelistyo Adi $^{3}$ \\ 1,2,3 Jurusan Keperawatan, Poltekkes Kemenkes Semarang
}

\section{Article Info}

\section{Article History:}

Accepted November 23rd 2018

Key words:

Masase Fundus Uteri

Tinggi Fundus Uteri

Postpartum

\begin{abstract}
Di dalam masa postpartum terdapat suatu proses yang disebut dengan proses involusi uteri atau kembalinya uterus ke keadaan normal atau sebelum hamil. Secara normal penurunan tinggi fundus uteri turun $1 \mathrm{~cm}$ setiap harinya, dan pada hari ke 7 postpartum tinggi fundus uteri berada pada ketinggian $5 \mathrm{~cm}$, untuk mempercepat proses penurunan tinggi fundus uteri dapat dilakukan dengan masase fundus uteri. Untuk itu peneliti ini bertujuan untuk mengetahui adakah pengaruh masase fundus uteri dengan pendidikan kesehatan (video masase fundus uteri) terhadap penurunan tinggi fundus uteri pada ibu postpartum di RSUD Pandan Arang Boyolali. Jenis penelitian yang digunakan adalah quasi exsperiment dengan rancangan post test only and with control grup design. Penelitian ini dilakukan pada 30 responden dengan teknik consecutive sampling. Selanjutnya data penelitian di analisa menggunakan uji Mann-Whitney. Hasil penelitian didapatkan mean rank kelompok perlakuan 8,73 dan kelompok kontrol 22,27 dengan $p$ value $0,000(<0,05)$ dapat disimpulkan ada pengaruh masase fundus uterui dengan pendidikan kesehatan menggunakan video masase fundus uteri terhadap penurunan tinggi fundus uteri.
\end{abstract}

\section{PENDAHULUAN}

Angka Kematian Ibu (AKI) menjadi salah satu indikator penting dari derajat kesehatan masyarakat. AKI menggambarkan jumlah wanita yang meninggal dari suatu penyebab kematian terkait dengan gangguan kehamilan atau penanganannya (tidak termasuk kecelakaan atau kasus insidentil) pada selama kehamilan, melahirkan, dan dalam masa nifas (42 hari setelah melahirkan) tanpa memperhitungkan lama kehamilan per 100.000 kelahiran hidup (Dinas Kesehatan Kabupaten Boyolali, 2015). AKI di Indonesia pada tahun 2012 adalah sebesar 359 per
100.000 kelahiran hidup. Masalah kematian ibu di Indonesia masih didominasi oleh tiga faktor yaitu perdarahan, hipertensi dalam kehamilan, dan infeksi (Kementerian Kesehatan RI, 2015).

Berdasarkan data profil kesehatan Kabupaten Boyolali pada tahun 2014, jumlah kematian ibu di Kabupaten Boyolali sebesar 14 orang atau sekitar 93.05/100.000 kelahiran hidup, angka tersebut sedah memenuhi target MDG's. Dari 14 tersebut jumlah kematian karena perdarahan di Kabupaten Boyolali sebanyak 7,14\% dari seluruh jumlah kematian. Kondisi ibu saat meninggal pada waktu

Corresponding author:

Elisa

elisa_maulana@ymail.com

Jurnal Ilmu Keperawatan Maternitas, Vol 1 No 2, Nov 2018

e-ISSN 2621-2994 
hamil $35,72 \%$ dan paling banyak pada masa nifas yaitu $64,28 \%$ dari jumlah angka kematian ibu yang terjadi (Dinas Kesehatan Kabupaten Boyolali, 2015).

Masa nifas merupakan masa pertama dimana setelah plasenta lahir dan berakhir ketika alat-alat kandungan kembali seperti keadaan sebelum hamil. Masa ini berlangsung selama kurang lebih 6 minggu. Pada masa nifas terdapat suatu proses yang disebut involusi uteri. Involusi uteri merupakan kembalinya uterus ke keadaan sebelum hamil, baik posisi maupun bentuk. Ada tiga proses yang berperan dalam pengembalian uterus ke keadaan sebelum hamil yaitu, kontraksi uterus, pengeluaran lokia, dan penurunan tinggi fundus uteri. Apabila kontraksi uterus tidak berjalan dengan baik dapat mengakibatkan perdarahan dan tinggi fundus uteri mengalami penurunan yang lambat (Rukiyah, 2011). Secara normal proses penurunan tinggi fundus uteri ini terus berlangsung dengan penurunan $1 \mathrm{~cm}$ setiap harinya, pada hari ke 7 tinggi fundus uteri berkisar $5 \mathrm{~cm}$ dan hari ke 10 tinggi fundus uteri tidak teraba di simfisis pubis (Bahiyatun, 2009).

Ada beberapa faktor yang dapat mempengaruhi proses terjadinya involusi uteri, diantaranya adalah mobilisasi dini, pengosongan kandung kemih, laktasi, dan masase fundus uteri (Nababan, 2011). Masase uterus merupakan tindakan nonfarmakologi yang dilakukan untuk mempertahankan kontraksi uterus tetap baik sehingga dapat mencegah terjadinya perdarahan. Masase dilakukan dengan meletakkan tangan di abdomen bagian bawah ibu dan merangsang uterus dengan pijatan yang teratur untuk merangsang kontraksi uterus (Hofmeyr, 2013). Kontraksi uterus juga merupakan bagian dari involusi uterus yang dapat mempengaruhi tinggi fundus uteri. Masase fundus uteri dapat dilakukan oleh tenaga kesehatan, keluarga, dan pasien itu sendiri setelah mendapatkan penjelasan atau pendidikan kesehatan mengenai masase fudus uteri baik melalui gambar, video, atau media yang lainnya.

Data yang didapat dari hasil wawancara pada ibu postpartum di RSUD Pandan Arang Boyolali mengatakan bahwa 9 dari 10 orang ibu postpartum tidak mengetahui tentang masase fundus uteri. Untuk itu pemberian materi pendidikan kesehatan mengenai masase fundus uteri dapat diberikan untuk meningkatkan pengetahuan ibu baik menggunakan media ataupun tanpa media.

Berdasarkan hasil penelitian yang dilakukan oleh Ambarwati, Wiyati, dan Sujiyati tahun 2010, media yang paling efektif digunakan adalah video, karena dengan menggunakan video melibatkan lebih banyak indra dibandingkan dengan metode yang lain dan memungkinkan untuk menerima materi lebih banyak atau lebih dapat dipahami oleh audiance dibanding dengan metode yang lain. Kelebihan video juga dapat menggambarkan keadaan nyata atau memberikan informasi nyata seperti aslinya yang menyebabkan informasi dapat tersimapan lama dan mudah untuk diingat atau bersifat mudah memberi kesan, dapat diterapkan berulang-ulang. Maka dari itu peneliti tertarik melakukan penelitian mengenai pengaruh masase fundus uteri dengan pendidikan kesehatan (video masase fundus uteri) terhadap penurunan tinggi fundus uteri ibu postpartum.

\section{METODE}

Penelitian quasy-experiment, dengan rancangan penelitian yang digunakan adalah posttest with control group design. Teknik sampling yang dipakai adalah consecutive sampling. Sampel yang digunakan dalam penelitian ini adalah ibu postpartum yang melahirkan per vagina di RSUD Pandan Arang Boyolali pada periode 9 Januari - 8 Februari 2017 yang memenuhi kriteria inklusi dan esklusi (30 responden). Variabel independen penelitian ini adalah pemberian video masase fundus uteri sedangkan variabel dependen adalah penurunan tinggi fundus uteri. Pada kelompok intervensi 
pemberian video dilakukan di rumah sakit, penayangan video kurang lebih 2-3 kali penayangan, yang tujuannya ibu paham dan bisa melakukan masase fundus uteri secara mandiri baik saat di rumah sakit ataupun di rumah, masase dilakukan selama 7 hari 1 kali setiap pagi selama 3-10 menit. Pada kelompok kontrol tidak dilakukan penayangan video. Selanjutnya peneliti kontrak waktu untuk pengukuran TFU hari ke-7 di rumah responden. Pengumpulan data menggunakan lembar observasi dan alat berupa metline. Hasil dianalisis menggunakan uji Mann-Whitney.

\section{HASIL}

\section{Karakteristik Responden}

Tabel 1

Distribusi frekuensi karakteristik berdasarkan umur, pendidikan, paritas, dan pekerjaan responden di ruang Dahlia RSUD Pandan Arang Boyolali, Januari-Februari

\begin{tabular}{lcccc}
\multicolumn{1}{c}{$\begin{array}{c}2017 \\
\text { Karakteristik }\end{array}$} & $\begin{array}{c}\text { Kelompok } \\
\text { Intervensi }\end{array}$ & \multicolumn{2}{c}{$\begin{array}{c}\text { Kelompok } \\
\text { kontrol }\end{array}$} \\
& f & \% & f & $\%$ \\
\hline Umur & & & & \\
$20-25$ & 6 & 40,0 & 5 & 33,3 \\
$26-30$ & 5 & 33,3 & 5 & 33,3 \\
$31-35$ & 4 & 26,7 & 5 & 33,3 \\
\hline Pendidikan & & & & \\
SD & 1 & 6,7 & 2 & 13,3 \\
SMP & 9 & 60,0 & 6 & 40,0 \\
SMA/SMK & 4 & 27,6 & 7 & 46,7 \\
D3 & 1 & 6,7 & 0 & 0 \\
\hline Paritas & & & & \\
1 & 5 & 33,3 & 5 & 33,3 \\
2 & 9 & 60,0 & 7 & 46,7 \\
$>2$ & 1 & 6,7 & 3 & 20,0 \\
\hline Pekerjaan & & & & \\
IRT & 9 & 60,0 & 10 & 66,7 \\
Swasta & 4 & 16,7 & 5 & 33,3 \\
Petani & 2 & 13,3 & 0 & 0 \\
\hline
\end{tabular}

Tabel 1 didapatkan hasil pada kelompok intervensi menunjukan data paling banyak adalah pada umur 20-25 (40,0\%) dengan pendidikan SMP $(60,0 \%)$, jumlah paritas sebanyak 2 kali paritas $(60,0 \%)$, dan pekerjaan sebagai IRT $(60,0 \%)$. Pada kelompok kontrol umur responden berdistribusi merata (33,3\%), dengan pendidikan paling banyak SMA/SMK $(46,7 \%)$, jumlah parits sebanyak 2 kali paritas $(46,7 \%)$, dan pekerjaan sebagai IRT $(66,7 \%)$.

2. Hasil Pengukuran Tinggi Fundus Uteri Hari Ke-7 Postpartum

Tabel 2

Hasil pengukuran tinggi fundus uteri pada hari ke 7 pada ibu post partum di ruang Dahlia RSUD Pandan Arang Boyolali,

\begin{tabular}{lcc}
\multicolumn{3}{c}{ Januari-Februari 2017} \\
Nilai & $\begin{array}{c}\text { Kelompok } \\
\text { Intervensi }\end{array}$ & $\begin{array}{c}\text { Kelompok } \\
\text { Kontrol }\end{array}$ \\
\hline Minimum & 0,00 & 5,00 \\
Maximum & 6,00 & 8,00 \\
Mean & 3,40 & 6,53 \\
\hline
\end{tabular}

Tabel 2 menunjukan bahwa TFU pada hari ke-7 pada kelompok intervensi didapatkan nilai minimum berada pada $0,00 \mathrm{~cm}$, nilai maksimum $6,00 \mathrm{~cm}$, dengan mean $3.40 \mathrm{~cm}$, sedangkan pada kelompok kontrol nilai minimum $5,00 \mathrm{~cm}$, nlai maksimum $8,00 \mathrm{~cm}$, dengan mean $6,53 \mathrm{~cm}$.

3. Perbedaan Penurunan Tinggi Fundus Uteri kelompok intervensi dan kelompok kontrol

Tabel 3

Perbedaan penurunan tinggi fundus uteri pada kelompok intervensi dan kelompok kontrol di ruang Dahlia RSUD Pandan Arang Boyolali, Januari-Februari 2017

\begin{tabular}{lccc} 
& \multicolumn{2}{c}{$(\mathrm{n}=30)$} & \\
\hline Karakteristik & Responden & $\begin{array}{c}\text { Mean } \\
\text { Rank }\end{array}$ & p value \\
$\begin{array}{l}\text { Dilakukan } \\
\text { masase }\end{array}$ & 15 & 8.73 & .000 \\
\hline $\begin{array}{l}\text { Tidak } \\
\text { dilakukan } \\
\text { masase }\end{array}$ & 15 & 22.27 & \\
\hline
\end{tabular}

Berdasarkan tabel 4.3 diketahui bahwa secara statistik hasil uji analisis menggunakan uji Mann-Whitney diperoleh $\mathrm{p}$ value $0,000(<0,05)$, maka hipotesis nol (Ho) ditolak dan hipotesis alternatif (Ha) diterima. Sehingga dapat disimpulkan bahwa ada pengaruh masase fundus uteri dengan pendidikan kesehatan menggunakan video masase fundus uteri terhadap penurunan tinggi fundus uteri ibu postpartum di ruang Dahlia Rumah Sakit Umum Daerah Pandan Arang Boyolali. 


\section{PEMBAHASAN}

\section{Karakteristik Responden}

Berdasarkan hasil analisa data didapatkan hasil bahwa data karakteristik responden berdasarkan usia pada kelompok intervensi paling banyak adalah pada rentang 20-25 tahun dan pada kelompok kontrol memiliki distribusi jumlah yang merata dari 20-25, 26-30, dan 31-35 tahun.

Umur merupakan salah satu faktor yang dapat mempengaruhi proses involusi uteri atau penurunan tinggi fundus uteri. Pada usia yang semakin tua, penurunan tinggi fundus uteri akan semakin lambat jika dibandingkan dengan usia yang lebih muda. Sesuai dengan data yang diperoleh, usia yang terbanyak adalah termasuk dalam usia yang muda dan masih baik dalam proses penurunan tinggi fundus uteri.

Data karakteristik berdasarkan tingkat pendidikan menunjukan bahwa, tingkat pendidikan yang paling banyak pada kelompok intervensi adalah SMP, sedangkan pada kelompok kontrol adalah SMA/SMK. Pada kelompok intervensi peneliti memberikan pendidikan kesehatan menggunakan video mengenai masase fundus uteri, sedangkan pada kelompok kontrol tidak.

Pendidikan mempengaruhi pengetahuan dan cara memahami apa yang telah dijelaskan (F Fitriana \& Dwi, 2012). Semakin tinggi pendidikan seseorang semakin banyak orang tersebut mendapat ilmu pengetahuan dan dapat lebih mudah menerima ilmu yang baru (Ambarwati, Wiyati, \& Sujiyati, 2010). Ilmu yang baru tersebut bisa didapat melalui usaha belajar. Usaha yang dilakukan merupakan aktivitas belajar dan sesuatu yang baru merupakan hasil yang diperoleh dari aktivitas belajar tersebut (Prayitno, 2009). Pendidikan yang tinggi dapat mempengaruhi proses penerimaan ibu dalam memahami video masase fundus uteri yang diberikan, sehingga ibu dapat melakukan masase dengan benar. Yang mana masase tersebut dapat mempengaruhi proses penurunan tinggi fundus uteri.

Data karakteristik responden menurut jumlah paritas baik pada kelompok intervensi maupun pada kelompok kontrol paling banyak adalah 2 paritas. Menurut Abdul Bari dalam Manurung (2014) menyebutkan bahwa paritas dapat mempengaruhi involusi uterus, karena otototot yang sering teregang memerlukan waktu yang lama untuk kembali. Menurut penelitian yang dilakukan oleh Apriliasari (2015) mengenai hubungan usia dan paritas dengan kejadian involusi ibu nifas di BPS Mojokerto menyebutkan bahwa ada hubungan antara paritas dengan kejadian involusi uteri dengan $\mathrm{p}$ value sebesar 0,007 $<0,05$. Jumlah paritas dapat mempengaruhi proses turunnya involusi uteri atau tinggi fundus uteri. Semakin banyak jumlah paritas ibu semakin lama proses involusi uterus terjadi, karena otot-otot uterus yang sering teregang akan memerlukan waktu yang lebih lama untuk kembali ke bentuk dan ukuran awal.

Data karakteristik responden menurut pekerjaannya, baik pada kelompok intervensi maupun kelompok kontrol pekerjaan paling banyak adalah sebagai ibu rumah tangga (IRT). Penelitian yang dilakukan oleh Martini (2012) mengenai hubungan inisiasi menyusui dini dengan tinggi fundus uteri ibu postpartum hari ketujuh di wilayah kerja Puskesmas Kotabumi II Lampung Utara menyebutkan bahwa, pekerjaan ibu tidak berpengaruh pada penurunan tinggi fundus uteri, tetapi aktivitas atau mobilisasi yang dilakukan oleh ibu sehari-hari akan mempengaruhi penurunan tinggi fundus uteri. Aktivitas atau mobilisasi dapat memperlancar darah ke dalam uterus sehingga kontraksi uterus akan baik dan fundus uteri akan menjadi keras. (Prihatini, 2014)

Sedangkan penelitian yang dilakukan oleh Wulan dan Pahonah (2010) mengenai pengaruh menyusui terhadap penurunan 
tinggi fundus uteri pada ibu postpartum primigravida di RSUD Dr. R. Sosodoro Djatmikoesoemo menyebutkan bahwa, ibu yang bekerja tidak bisa memberikan ASI secara ekslusif sehingga pelaksanaan menyusui kurang maksimal dan mempengaruhi sekresi hormon, produksi ASI, dan proses involusi uterus yang terjadi pada ibu.

Dapat ditarik kesimpulan bahwa pekerjaan tidak mempengaruhi seberapa besar penurunan tinggi fundus uteri pada ibu postpartum, tetapi aktivitvitas atau mobilisasi yang dilakukan oleh ibulah yang dapat mempengaruhi proses involusi uteri atau penurunan tinggi fundus uteri.

2. Penurunan Tinggi Fundus Uteri pada Kelompok Ibu Postpartum yang Diberikan Masase Fundus Uteri dengan Pendidikan Kesehatan Menggunakan Video Masase Fundus Uteri.

Hasil penelitian terhadap 15 sampel ibu postpartum yang diberikan masase fundus uteri dengan pendidikan kesehatan menggunakan video masase fundus uteri diperoleh data nilai terendah tinggi fundus uteri pada hari ke-7 postpartum adalah 0,00 $\mathrm{cm}$, sedangkan nilai tertinggi sebesar 6,00 $\mathrm{cm}$ dan rata-rata tinggi fundus uteri hari ke7 berada pada ketinggian 3,40 cm.

Pada penelitian ini peneliti menggunakan metode penayangan video untuk memberikan pemahaman mengenai cara melakukan masase fundus uteri dengan benar. Pemilihan media video didasarkan dari beberapa pertimbangan diantaranya adalah :

a. Video dapat merangsang minat, perhatian, serta dapat meningkatkan pemahaman dari orang yang menyaksikan video (Nurfathiyah, Mara, Siata, Farida, \& Aprollita, 2011).

b. Informasi dapat tersimpan lama dan mudah untuk diingat (Ambarwati, Wiyati, \& Sujiyati, 2010).

c. Mencakup wilayah perkotaan dan masyarakat pedesaan (Sulastri, 2012). d. Kemampuan media video juga dapat diandalkan pada bidang studi yang mempelajari keterampilan motorik dan melatih kemampuan kegiatan (Nugroho, 2015).

Kegiatan masase fundus uteri ini dapat dilakukan baik di rumah sakit ataupun di rumah ibu setelah ibu diberikan pengetahuan melalui penayangan video. Pemberian video rata-rata dilakukan sebanyak 2-3 kali penayangan, sehingga ibu bisa paham dan dapat mempraktekan tindakan masase fundu uteri secara mandiri.

Masase fundus uteri diduga dapat menstimulasi pengeluaran hormon prostaglandin sehingga menimbulkan kontraksi uterus (Hofmeyr, 2013). Kontraksi uterus tersebut merupakan salah satu dari bagian proses involusi uteri dan dapat berakibat pada penurunan tinggi fundus uteri.

Sesuai dengan proses fisiologis uterus, ibu postpartum tetap mengalami penurunan tinggi fundus uteri. Sehubungan dengan proses fisiologi uterus, setelah janin dilahirkan tinggi fundus uteri berada kirakira pada setinggi pusat. Setelah plasenta lahir tinggi fundus uteri kurang lebih 2 jari dibawah pusat. Secara normal tinggi fundus uteri mengalami penurunan $1 \mathrm{~cm}$ setiap harinya (Walyani \& Purwoastuti, 2015). Pada hari ke 7 TFU berkisar $5 \mathrm{~cm}$ dan hari ke 10 TFU tidak teraba di simfisis pubis (Bahiyatun, 2009). Normalnya uterus mencapai ukuran seperti semula berkisar dalam kurun waktu 6 minggu (Rukiyah, 2011).

Chooha dan Anusornteerakul (2014) dalam Mahasarakham Hospital Journal mengenai The Effects of Uterne Massage On Uterine Contraction During Postpartum Period mengungkapkan bahwa setelah dilakukan masase uterus rata-rata tinggi fundus uteri segera setelah melahirkan berada pada $10,95 \pm 1,10 \mathrm{~cm}$, kemudian pada periode 2 jam postpartum setinggi $12,31 \pm 1,49 \mathrm{~cm}$, dan setelah 24 jam postpartum setinggi 9,54 $\pm 1,49 \mathrm{~cm}$. Dapat disimpulkan bahwa tinggi 
fundus uterus postpartum 24 jam dan 2 jam postpartum mengalami peurunan yang signifikan dan didapatkan nilai $\mathrm{p}<0,01$.

3. Penurunan Tinggi Fundus Uteri pada Kelompok Ibu Postpartum yang Tidak Diberikan Masase Fundus Uteri dengan Pendidikan Kesehatan Menggunakan Video Masase Fundus Uteri

Hasil penelitian terhadap 15 sampel ibu postpartum yang tidak diberikan masase fundus uteri dengan pendidikan kesehatan menggunakan video masase fundus uteri diperoleh data nilai terendah tinggi fundus uteri pada hari ke 7 postpartum adalah 5,00 $\mathrm{cm}$, sedangkan nilai tertinggi adalah $8,00 \mathrm{~cm}$, dan rata-rata tinggi fundus uteri hari ke-7 berada pada ketinggian $6,53 \mathrm{~cm}$.

Hal-hal yang dapat menyebabkan proses penurunan tinggi fundus uteri normal atau tidak normal adalah kontraksi uterus, karena kontraksi uterus yang lemah akan mengakibatkan proses involusi berjalan lambat atau tidak normal (Widyastuti, Suherni, \& Marianingsih, 2013). Aktivitas yang kurang juga dapat mempengaruhi proses penurunan tinggi fundus uteri, karena dengan aktivitas yang kurang akan mempengaruhi pengeluaran lokhea sehingga proses involusi akan berjalan lambat. Jika ibu melakukan aktivitas (ambulasi) dengan baik, maka akan berpengaruh terhadap percepatan proses involusi dan tidak akan menyebabkan terjadinya sub involusi pada ibu post partum (Esyuananik \& Laili, 2015).

\section{Perbedaan Penurunan Tinggi Fundus Uteri Hari Ke 7 pada Kedua Kelompok}

Hasil penelitian mengenai pengaruh masase fundus uteri dengan pendidikan kesehatan menggunakan video masase fundus uteri pada ibu post partum di RSUD Pandan Arang Boyolali yang di uji menggunakan uji MannWhitney didapatkan nilai p $0,000(<0,05)$ yang berarti bahwa ada perbedaan antara nilai penurunan tinggi fundus uteri yang dilakukan masase fundus uteri dengan pendidikan kesehatan menggunakan video masase fundus uteri dengan yang tidak dilakukan masase fundus uteri dengan pendidikan kesehatan menggunakan video masase fundus uteri.

Pada kelompok intervensi diberikan pendidikan kesehatan mengenai masase fundus uteri menggunakan media video, tujuannya adalah untuk memandirikan ibu, sehingga ibu bisa melakukan masase fundus uteri secara mandiri baik di rumah sakit maupun di rumah.

Masase fundus uteri ini diduga merangsang kontraksi uterus melalui stimulasi pelepasan prostaglandin (Hofmeyr, 2013). Ada beberapa teori yang berkaitan dengan prostaglandin salah satunya mengenai teori penurunan kadar hormon progesteron pada akhir kehamilan yang mengakibatkan meningkatnya kontraksi uterus dikarenakan sintesa prostaglandin di chorioamnion. Teori ke dua mengenai teori rangsangan estrogen, yang mana estrogen menyebabkan iritability miometrium, estrogen juga memungkinkan sintesa prostaglandin pada decidua dan selaput ketuban yang menyebabkan kontraksi uterus (miometrium) (Oktarina, 2016).

Penelitian ini sejalan dengan penelitian yang dilakukan oleh Nababan (2011) mengenai Efektivitas Massase Uterus terhadap Penurunan Tinggi Fundus Uteri pada Kala IV Persalinan di Klinik Bersalin Mariani Medan. Hasil pengumpulan data diuji menggunakan uji paired t-tes didapatkan hasil bahwa tinggi fundus uteri mengalami penurunan yang signifikan yaitu sekitar 125-3 millimeter setelah dilakukan masase uterus dengan nilai $\mathrm{p}=0,000(\mathrm{p}<0,05)$ yang dapat diartikan bahwa masase uterus berpengaruh terhadap penurunan tinggi fundus uteri.

Pada kelompok kontrol terdapat empat responden yang penurunan tinggi fundus uterinya normal $(5 \mathrm{~cm})$. Banyak hal yang dapat mempengaruhi normal atau tidak normalnya TFU pada hari ke-7, diantaranya 
adalah mobilisasi dini, pengosongan kandung kemih, usia, paritas, inisiasi menyusui dini atau seberapa sering ibu menyusui bayinya.

Jumlah paritas merupakan salah satu faktor yang dapat mempengaruhi penurunan TFU, (Maryunani, 2009) penelitian yang dilakukan oleh Apriliasari (2015) menyebutkan bahwa ada hubungan antara paritas dengan kejadian involusi uteri dengan $\mathrm{p}$ value sebesar $0,007<0,05$, namum menurut Esyuananik dan Laili (2015) mengenai peranan mobilisasi dini terhadap involusi uteri pada ibu postpartum menyebutkan bahwa, jumlah paritas dan pengalaman bersalin ibu yang sudah banyak dapat mempengaruhi penurunan tinggi fundus uteri tetap turun secara normal, dengan jumlah paritas dan pengalaman yang banyak ibu tidak takut untuk melakukan mobilisasi pada masa post partum. Hal ini sesuai dengan penelitian yang dilakukan oleh Pratiwi (2012) mengenai faktor-faktor yang berhubungan dengan percepatan involusi uteri pada ibu postpartum pervaginam di Ruang Kebidanan RSUD Toto Kabila Kab. Bone Bolango didapatkan hasil $p$ value $0,672>\alpha=0,05$ artinya tidak ada hubungan antara paritas dengan percepatan involusi uteri pada ibu postpartum.

Selain paritas, mobilisasi dapat mempengaruhi proses penurunan tinggi fundus uteri. Sesuai dengan penelitian yang dilakukan oleh Esyuananik dan Laili (2015) menyebutkan bahwa mobilisasi dini mempunyai pengaruh yang baik terhadap proses penyembuhan dan pemulihan kesehatan ibu postpartum.

Prawirohardjo (2011) menjelaskan bahwa mobilisasi dini dapat meningkatkan tonus otot yang dibutuhkan untuk mempercepat proses involusi uteri dan dapat mengurangi insiden perdarahan postpartum. Setelah melahirkan, selain dilakukan mobilisasi dini biasanya petugas kesehatan menganjurkan ibu untuk BAK secara teratur, hal ini dilakukan untuk memastikan kandung kemih tetap kosong, apabila kandung kemih penuh akan menyebabkan terjadinya perdarahan. Diharapkan dengan itu, ibu agar tidak menahan BAK setelah proses melahirkan agar kontraksi uterus berjalan dengan baik (Esyuananik \& Laili, 2015).

Selain beberapa faktor yang telah disebutkan di atas, menyusui merupakan salah satu faktor selanjutnya. Berdasarkan hasil penelitian yang dilakukan oleh Wulan dan Patonah (2010) menyebutkan bahwa, menyusui merupakan salah satu faktor pendukung yang berperan penting dalam memperbaiki involusi uterus. Karena dengan menyusui dapat merangsang hormon oksitosin yang menyebabkan kontraksi sehingga pengembalian uterus ke keadan fisiologis lebih cepat.

Dari beberapa teori dan penelitian di atas, penelitian yang dilakukan mengenai masase fundus uteri dapat berpengaruh terhadap penurunan tinggi fundus uteri ibu postpartum. Secara fisiologis tinggi fundus uteri ibu postpartum tetap mengalami penurunan, tetapi dengan dilakukan masase fundus uteri dapat mempercepat penurunan tinggi fundus uteri yang terjadi pada ibu postpartum. Hal ini dapat dilihat dari ratarata penurunan TFU pada hari ke 7 postpartum pada kelompok intervensi sebesar 3,40 cm sedangkan sesuai teori yang ada tinggi normal TFU pada hari ke 7 adalah $5 \mathrm{~cm}$.

Namun pada kelompok yang tidak dilakukan masase fundus uteri tetap mengalami penurunan tinggi fundus uteri, walaupun hasil yang didapat pada rata-rata TFU hari ke-7 postpartum sebesar $6,53 \mathrm{~cm}$, tetapi terdapat hasil TFU normal dan tidak normal pada ibu postpartum, karena memang ibu postpartum tetap mengalami proses involusi uteri.

\section{REFERENSI}

Ambarwati, K., Wiyati, N., \& Sujiyati. (2010). Penggunaan Leaflet dan Video dalam Konseling Menyusui Hasil Konseling Menyusui pada Ibu Primipara Studi Di 
Puskesmas Mergangsan Yogyakarta. Poltekkes Kemenkes Yogyakarta, Yogyakarta:

Apriliasari, D. (2015). Hubungan Usia dan Paritas dengan Kejadian Involusi Ibu Nifas di BPS Mojokerto. Poltekkes Majapahit, Kebidanan

Bahiyatun. (2009). Buku Ajar Asuhan Kebidanan Nifas Normal. Jakarta. : EGC

Chooha, U. (2014, September - Desember). The Effects Of Uterine Massage On Uterine Contraction During Postpartum Period. Mahasarakham Hospital Journal, 11 No. 3

Darma, K. K. (2011). Metodologi Penelitian Keperawatan: Pedoman Melaksanakan dan Mnerapkan Hasil Penelitian. Jakarta: TIM

Dinas Kesehatan Kabupaten Boyolali. (2015). Profil Kesehatan kabupaten Boyolali Tahun 2014

Esyuananik, \& Laili, A. N. (2015). Peranan Mobilisasi Dini Terhadap Involusi Uteri Ibu Post Partum . Poltekkes Surabaya, Kebidanan, Surabaya

F Fitriana, I., \& Dwi, L. (2012). Perbedaan Penurunan Tinggi Fundus Uteri Berdasarkan Jenis Persalinan Pada Ibu Nifas Fisiologis dan Post Sectio Caesarea. Jurnal Midpro, 2

Hariyanto. (2012). Dipetik Desember 5, 2016, dari BelajarPsikologi.Com: http://belajarpsikologi.com/klasifikasimedia-pembelajaran/

Hofmeyr, G. (2013). Dipetik Oktober 11, 2016, dari Uterine Massage for Preventing Postpartum

Haemorrhage:http://onlinelibrary.wiley.co $\mathrm{m} /$ doi/10. 1002/14651858.CD006431.pub3/pdf

Kementerian Kesehatan RI. (2015). Profil Kesehatan Indonesia 2014
Lisni, A., Misrawati, \& Utami, G. T. (2015, Oktober). Perbandingan Efektifitas Senam Nifas dan Pijat Oksitosin Terhadap Involusi Uteri pada Ibu Post Partum. JOM, 2(2), 927933

Manurung, E. L. (2014). Faktor-Faktor yang Berhubungan dengan Involusi Uteri pada Ibu Postpartum di Klinik Linda Silalah Pancur Batu Desa Hulu. KTI, Akademi Kebidanan Abdi Hudsada, Medan

Martini. (2012). Hubungan Inisiasi Menyusui Dini dengan Tinggi Fundus Uteri Ibu Postpartum Hari Ke-Tujuh Di Wilayah Kerja Puskesmas Kotabumi II Lampung Utara. Thesis, universitas Indonesia, Depok.

Maryunani. (2009). Asuhan Masa Nifas. Yogyakarta: Mitra Cendikia

Nababan, E. (2011). Dipetik Oktober 10, 2016, dari Efektivitas Massase Uterus terhadap Penurunan Tinggi Fundus Uteri pada Kala IV Persalinan di Klinik Bersalin Mariani-Medan: http: //repository.usu.ac.id /handle/123 456789/24415

Nugroho, T. A. (2015). Pengaruh Penggunaan Media Video Pembelajaran Terhadap Ketrampilan Proses IPA dan Hasil Belajar IPA pada Siswa Kelas V SD Negeri Rejowinangun 1 Yogyakarta Tahun Ajaran 2014/2015. Skripsi, Universitas Negeri Yogyakarta, PGSD, Yogyakarta

Nurfathiyah, P., Mara, A., Siata, R., Farida, A., \& Aprollita. (2011). Pemanfaatan Video Sebagai Media Penyebaran Inovasi Pertanian. Jurnal Pengabdian Pada Masyarakat No. 52

Oktarina, M. (2016). Buku Ajar Asuhan Kebidanan Persalinan dan Bayi Baru Lahir (1 ed.). Yogyakarta: Deepublish

Pratiwi, S. (2014). Faktor-faktor yang Berhubungan dengan Percepatan Involusi Uteri pada Ibu Postpartum Pervaginam di Ruang Kebidanan RSUD Toto Kabila Kab. Bone Bolango. Skripsi, Universitas Negeri 
Gorontalo, Jurusan Keperawatan, Fakultas Ilmu-Ilmu Kesehatan dan Keolahragaan

Prawirohardjo, S. (2011). Ilmu Kebidanan Sarwono prawirohardjo (4 ed.). Jakarta: PT Bina Pustaka

Prawirohardjo, S. (2011). Ilmu Kebidanan Sarwono Prawirohardjo (4 ed.). Jakarta: PT Bina Pustaka

Prayitno. (2009). Dasar Teori dan Praksis Pendidikan. Jakarta: Penerbit Gasindo

Prihatini, S., D. (2014, September). Pengaruh Mobilisasi Dini Terhadap Penurunan Tinggi Fundus Uteri Pada Ibu Nifas Di Paviliun Melati RSUD Jombang. Jurnal Edu Health, $4(2)$

Rahayu, A. P. (2016). Panduan Praktikum Keperawatan Maternitas (1 ed.). Yogyakarta: Deepublish

Reeder, S., Martin, L., \& Griffin, D. (2011). Keperawatan Maternitas: Kesehatan Wanita, Bayi, Dan Keluarga (18 ed.). Jakarta: EGC

Rini, M. (2013). Tingkat Pengetahuan Ibu Nifas Tentang Gizi Masa Nifas di RSUD Pandan Arang Boyolali. KTI, STIK Kusuma Husada, Surakarta

Rukiyah, A. (2011). Asuhan Kebidanan III (Nifas). Jakarta: CV Trans Info Media

Safitri, I. K., Ducha, N., \& Isnawati. (2015, September). Kelayakan Teoritis Media Animasi Interaktif Elektronik Game Flash Sirkulasi Manusia. BioEdu Berkah Ilmiah Pendidikan Biologi, IV(3)
Sulastri. (2012). Pengaruh Penyuluhan Kesehatan Menggunakan Video dalam Pemeriksaan Payudara Sendiri (Sadari) Terhadap Perubahan Pengetahuan dan Sikap Remaja Putri Di SMAN 9 Balikpapan Tahun 2012. Universitas Hasanudin, Fakultas Kesehatan Masyarakat, Makasar

Walyani, E. S., \& Purwoastuti, E. (2015). Asuhan Kebidanan Masa Nifas \& Menyusui. Yogyakarta: PT. Pustaka Baru

Widyastuti, Y., Suherni, \& Marianingsih, E. (2013, Desember). Pengaruh Senam Nifas Terhadap Kecepatan Penurunan Tinggi Fundus Uteri (TFU) Pada Primipara Post Partum. Jurnal Kebidanan dan Keperawatan, 9(2)

Wulan, F., \& Pahonah, S. (2010, Desember). Pengaruh Menyusui Terhadap Penurunan Tinggi Fundus Uteri Pada Ibu Post Partum Primigravida Di RSUD Dr. R. Sosodoro Djatmikoesoemo Bojonegoro. Asuhan Kesehatan, 1(1)

Yenita, S. (2011). Faktor Determinan Pemilihan Tenaga Penolong Persalinan di Wilayah Kerja Puskesmas Desa Baru Kabupaten Pasaman Barat Tahun 2011. Thesis, Universitas Andalas

Yohana, A. (2011). Studi Tentang Media Pembelajaran YAng Digunakan Pada Mata Pelajaran Seni Budaya Bidang Seni Rupa Di SMP Negeri 1 Probolinggo. Skripsi, Universitas Negeri Malang, Fakultas Sastra, Malang 